\title{
Mencermati Perilaku Kekerasan dan Paradigma Sosial
}

\author{
Dian Wahyuni $P$.
}

The effect of violence action toward victims that undergoes more is traumatically experience. This experience is difficult to lose from the victims. In this sense, the problems will be followed by other problems either physically, psychologically, or those of social. The above effect is experienced more with stigma, that tends to make the victims to be introvert, etc. Besides, society tend to sentence the victims, so does information media without empathy and private appreciation publishes the violence cases clearly: However, the violence is something to be sentenced. There is no nation in the world has right to conduct the violence action.

Kata Kunci: kekerasan, negara, sosial, korban, dan media

$\mathrm{D}$ engan semakin terbukanya saluran komunikasi dan informasi di bidang sosial-politik di Indonesia, maka akses masya-rakat terhadap informasi tentang berbagai bentuk tindak kekerasan di berbagai tempat dan tingkatan, dimana negara terlibat di dalamnya dan dimana kalangan perempuan sebagai korbannya, menjadi semakin terbuka. Sebagai contoh adalah pember-lakuan daerah operasi militer di Aceh, kekerasan di Timor Timur dan di Irian Jaya, kekerasan Mei 1998, perkosaan dan pembunuhan perempuan di berbagai tempat di Indonesia, dan sebagainya. Akhirakhir ini kita semakin sering disuguhi dengan berita-berita di media massa tentang tindak kekerasan, baik yang terjadi di kalangan publik maupun di dalam rumah tangga. Ada satu bentuk tindak kekerasan, yang seringkali sukar dicari siapa pelakunya namun sangat dirasakan kehadirannya oleh masyarakat umumnya dan kalangan perempuan khususnya; yaitu tindak kekerasan dimana negara terlibat di dalamnya. Keterlibatan negara bisa jadi bersifat langsung misalnya melalui aparat militer dan polisi (state directed), atau tidak langsung (state sponsored) misalnya melalui berbagai sarana, cara, dan partisipasi berbagai pihak di luar negara. Dalam hal ini; negara sendiri bisa dianggap melakukan tindak kekerasan ketika berbagai kejadian yang menimpa banyak orang, terutama perempuan, seperti pelecehan seksual, diskriminasi, penganiayaan, perkosaan, hingga pembunuhan, tidak dapat dicegah atau bahkan dibiarkan oleh negara (violence by omission).

\section{Kekerasan terhadap Kehidupan} Anak

Berdasarkan data Komisi Nasional Perlindungan Anak, kasus tindak kekerasan terhadap anak tahun 2004 mencapai 544 kasus, tahun 2005 meningkat menjadi 736 kasus, dan Januari 2006 telah terjadi 69. 
kasus. Jumlah ini diyakini lebih banyak lagi dan merupakan 'fenomena gunung es mengingat banyak kasus yang tidak terlaporkan maupun sengaja dirahasiakan karena dianggap aib, baik oieh korban, keluarga, maupun masyarakat sekitarnya. Dampak dari tindak kekerasan terhadap anak. yang paling dirasakan adalah pengalaman traumatis yang susah dihilangkan pada diri anak, yang berlanjut pada permasalahan-permasalahan lain, baik fisik, psikologis, maupun sosial. Dampak tersebut semakin terasa dengan adanya stigma yang melekat pada mereka, yaitu kecenderungan korban menyalahkan diri sendiri, menutup diri, menghukum diri, dan menganggap dirinya aib. Selain itu ada kecenderungan masyarakat menyalahkan korban, demikian pula media informasi yang sering tanpa empati dan penghargaan privacy memberitakan kasus secara terbuka. Bagi anak-anak yang menjadi korban tindak kekerasan, pemerintah menyiapkan rumah perlindungan selama proses penyelesaian kasus. Ini biasanya memerlukan waktu hingga enam bulan. Masa perlindungan dapat diperpanjang berdasarkan evaluasi kasus korban tindak kekerasan.

Tujuannya adalah anak-anak merasa aman dan terlindungi dari berbagai ancaman yang terkait dengan kasusnya. Mereka yang dapat diterima di rumah perlindungan adalah anak-anak yang sedang menjalani proses penyelesaian kasus, baik rehabilitasi medis maupun persidangan. Rumah perlindungan disediakan untuk anak-anak korban tindak kekerasan hasil rujukan dari penampungan sementara atau rujukan lainnya berdasarkan penilaian bahwa anak siap berada dalam rumah perlindungan dan berusia di bawah 18 tahun.

Sejak dioperasionalkannya pada September 2004, Rumah Perlindungan Sosial
Anak sudah menangani 76 kasus anak korban tindak kekerasan, beberapa di antaranya ada anak yang diperlakukan salah, anak korban pemerkosaan, dan anak korban perdagangan (trafficking). (LOK) Rancangan Perubahan UU No 23/1992 tentang Kesehatan diusulkan DPR periode 19992004. Ketua DPRAkbar Tandjung (waktu itu) telah menyampaikan surat kepada Presiden Megawati Soekamoputri untuk mendapatkan persetujuan pemerintah, namun pembahasannya ditunda karena berakhirnya masa jabatan Presiden dan DPR.

Pada Rapat Dengar Pendapat Umum Komisi IX DPR periode 2004-2009 tanggal 27 Juni 2005, amandemen itu ditetapkan sebagai agenda prioritas DPR tahun 2005. Dalam sidang pleno tanggal 28 Juni, semua fraksi DPR menyetujui usulan amandemen itu dan menyerahkan pembahasan lebih lanjut kepada Komisi IX. "Sekarang menunggu penunjukan institusi pemerintah yang akan membahasnya bersama DPR. Tetapi, menurut Menteri Perundangundangan dan HAM, Amandemen RUU Kesehatan juga menjadi prioritas pemerintah," ujar Rita S Kolibonso dari YKP.

\section{Kekerasan terhadap Kesehatan}

Dr Sri Kusyuniati yang pernah bekerja untuk program kesehatan perempuan dan anak. John Hopkin's University mengemukakan rumitnya persoalan di balik isu kesehatan, termasuk kesehatan reproduksi, karena sifatnya kultural dan struktural. "Ditambah ketidakmampuan masyarakat mencerna informasi yang diterima, khususnya dari televisi," tambah Dr Adi Sasongko dari Yayasan Kusuma Buana, yang selama belasan tahun memberikan perhatian pada isu cacingan dan anemia pada anak. Kus mengatakan, berbagai solusi pemerintah masih memperlihatkan 
kecenderungan mengatasi masalah kesehatan secara kuratif. "Dengan paradigma seperti itu sangat sulit membuat target Tujuan Pembangunan Millenium (MDGs), apalagi mencapainya," tegasnya.

Delapan sasaran MDGs, menurut Kus, saling berkaitan. Kemiskinan, rendahnya tingkat pendidikan, kerusakan lingkungan, dan penyakit-penyakit infeksi sangat berpengaruh pada tingginya angka kematian ibu hamil dan melahirkan serta angka kematian bayi dan anak balita. Karena itu, sebenarnya, perspektif jender seharusnya digunakan mulai di tujuan pertama MDGs, yakni penghapusan kemiskinan. Implementasi perubahan paradigma kuratif ke paradigma sehat yang mengutamakan upaya promosi dan preventiftanpa mengabarkan pengobatan dan rehabilitasimenurut $\mathrm{dr}$ Adi, mengandung konsekuensi berat dan komitmen yang kuat. "Harus dilakukan pendidikan yang intensif sampai ke bawah tentang cara hidup sehat. Harus dilakukan penyadaran bahwa kesehatan adalah hak asasi manusia," tegas pengajar pada Fakultas Kesehatan Masyarakat Universitas Indonesia itu. Menurut dr Adi, banyak anak menderita cacingan dan anemia bukan karena kurang makan. "Di pulau Seribu, misalnya, uang jajan anak sampai Rp 50.000 per hari," lanjutnya.

\section{Wacana atau Pemikiran terhadap Kekerasan}

Kalau paradigma sehat menjadi pilihan, yang harus dilakukan adalah mendidik dan membangun perilaku dan gaya hidup sehat dalam arti luas. Artinya, tidak hanya mendidik pola makan, tetapi juga cara membelanjakan uang, memilih produk, dan lain-lain, juga pola-pola hubungan, termasuk hubungan seksual yang sehat dan ber-- tanggung jawab. Pada kenyàtaannya, kerja membangkitkan penyadaran tidak ringigan. "Prosesnya panjang, tak terlihat, häsilnya bertahap. Sementara kemajuan' lebih dipahami sebagai pembangunan fisik, instan. Pandangan tersebut membuat orang cenderung menyelesaikan persoalan di permukaan tanpa membongkar akar persoalan. Di bidang kesehatan, kata dr Adi Sasongko, ada yang disebut blanket treatment. Contohnya adalah, kampanye tablet besi untuk mengurangi anemia dan kampanye obat cacing untuk pengidap cacingan. "Itu pendekatan kuratif. Tidak ada penyuluhan dan pendidikan tentang ketersediaan sumber-sumber alamiah di sekitar kita," ujar dr Adi. Padahal, obat cacing tak ada gunanya kalau tidak ada pembenahan sanitasi, akses ke air bersih, dan orang tak tahu soal gizi. Kampanye seperti itu juga mendorong ketergantungan, tak memberi sumbangan apa pun pada upaya pencegahan.

Tanpa kesadaran akan akibat lebih jauh dari cacingan dan anemia, khususnya, pada anak perempuan, kondisinya tak mudah diperbaiki. Pun gizi buruk. "Kondisi itu menyebabkan mereka rentan terhadap kehamilan dan persalinan,." kata dr Adi. Data YKP menunjukkan, 57 persen perempuan remaja di Indonesia menderita anemia. Anemia merupakan salah satu pemicu pendarahan saat hamil dan melahirkan. Berbagai survei menunjukkan, $40-60$ persen penyebab kematian ibu hamil dan melahirkan adalah karena pendarahan. "Angka itu tak pernah turun," ujar Ninuk Widyantoro dari YKP, seraya menyebut anemia sebagai isu kritis yang tak banyak mendapat perhatian. Angka kematian ibu hamil dan melahirkan (AKI) merupäkan indikator paling jelas dari rendahnya posisi perempuan. Di Indonesia angkanya tertinggi di Asia, yakni 307 per 100.000 kelahiran hidup'(dāta 
resmi). Data Ditjen Bina Kesehatan Masyarakat Departemen Kesehatan RI memper-kirakan sumbangan penghentian kehamilan tidak aman terhadap AKI antara 30-50 persen. Dr Adi menyatakan, empat faktor yang memengaruhi derajat kesehatan masyarakat adalah lingkungan, perilaku, pelayanan kesehatan, semuanya dalam arti luas, serta genetika. Karena itu, pendidikan kesehatan merupakan isu krusial. "Masih ada dokter yang tak memahami universal precaution," sambung dr Adi mengenai seorang dokter yang dalam suatu seminar mengungkapkan perlunya tes HIV untuk semua pasien baru supaya memberi rasa aman bagi petugas kesehatan. "Dokter itu lupa ada periode jendela untuk HIV," ujar dr Adi.

Menurut dia, pelayanan kesehatan jauh lebih luas artinya dari pelayanan medis saja. "Bukan rumah sakit dan puskesmas yang membuat derajat kesehatan masyarakat meningkat," tegasnya. Yang paling utama adalah bagaimana upaya untuk menciptakan dan membangun perilaku hidup sehat, lingkungan yang baik dan sehat, akses ke sumber gizi, kebijakan distribusi makanan, kebijakan pertanian, kebijakan penghapusan kemiskinan dan pemiskinan dalam arti luas," tegas dr Adi. Karena itu, pihak yang paling bertanggung jawab, menurut dr Adi, adalah pemerintah. "Mereka punya kewenangan mengelola sumber daya, seperti penerimaan pajak dan pemasukan lainnya. Karena itu, mereka merupakan penanggung jawab terbesar untuk penyelenggaraan kesehatan masyarakat dalam arti luas melalui alokasi sumber daya, anggaran, kebijakan, dan lainlain," tegas dr Adi. Setelah otonomi daerah diberlakukan, pemerintah daerah seperti berlomba-lomba membuat peraturan daerah. Di antara perda-perda tersebut tidak sedikit yang memojokkan perempuan.
Pusat Pendidikan dan Informasi Islam dan Hak-hak Perempuan Rahima sejak lebih tiga tahun ini bekerja sama dengan organisasi-organisasi perempuan di Garut, Cianjur, Tasikmalaya, dan Banten untuk melihat secara kritis berbagai peraturan daerah. Dalam temuan mereka yang dipublikasikan pada tahun 2004, salah satu yang diatur menyangkut posisi perempuan di masyarakat serta seksualitasnya. Di Tasikmalaya, misalnya, muncul surat edaran bupati tentang peningkatan kualitas ketakwaan dan keimanan yang isinya menganjurkan kepada siswi SD, SMP, SMA/SMK, lembaga kursus dan perguruan tinggi yang beragama Islam untuk mengenakan seragam yang menutup aurat. Dalam praktiknya, hal yang semula merupakan anjuran berubah menjadi kewajiban.

Menurut Koordinator Divisi Humas dan Jaringan Rahima Ade Kusumaningtias, formalisasi syariat Islam di Cianjur melalui cetak biru pemerintahan yang dinamai Gerbang Marhamah menyosialisasikan akhlak yang baik dengan masuk ke ruang lingkup keluarga melalui penyuluh akhlakul karimah. Di dalam penyuluhan ditanamkan domestikasi perempuan dengan menekankan bahwa kepala keluarga adalah lakilaki (suami) dan istri adalah ibu rumah tangga dan bila keluar rumah harus meminta izin suami. "Otomatis ada penanaman besar-besaran nilai-nilai domestikasi perempuan," kata Kusumaningtias. Di Aceh, Komnas Perempuan sudah menerima laporan kekerasan yang dialami tiga perempuan aktivis yang diangkut paksa oleh Polisi Syariah (WH) ke kantor WH karena mereka tidak mengenakan jilbab saat sedang duduk dan berbincang di depan kamar mereka di sebuah hotel seusai mengikuti lokakarya Jaringan Perempuan untuk Perdamaian. 
Ketua Koalisi Perempuan Indonesia (KPI) untuk Perdamaian Masruchah mengatakan, anggota KPI di sejumlah wilayah, seperti Bengkulu, Sulawesi Selatan, dan Bima, sedang membuat rancangan peraturan daerah dan sudah ada peraturan yang menghegemoni perempuan. Perda atau rancangan perda yang biasanya menyangkut moralitas itu dan ujungujungnya membawa perempuan kembalike dalam rumah, menjadi ibu rumah tangga, tidak memiliki hak untuk mengekspresikan diri. "Dalam situasi seperti ini sulit mengharapkan nantinya perempuan dapat berpartisipasi dalam ruang publik. Misalnya, Kusumaningtias melihat, perubahan besar yang disebabkan globalisasi menimbulkan kecemasan-kecemasan pada berbagai kelompok masyarakat, tetapi ketakutan dan kecemasan itu tidak seharusnya disikapi dengan melarang semua hal. Padahal, proses bersama dalam menghadapi perubahan itu menghasilkan hal-hal yang kemajuan. Jadi, perubahan itu hendaknya disikapi dengan arif sehingga menghasilkan kemajuan bersama.

Memasuki tahun 2006 situasi hak asasi perempuan mencatat beberapa perubahan ke arah keadaan yang lebih memberi, harapan walaupun persoalan kekerasan dan diskriminasi masih jauh lebih banyak lagi yang menunggu diselesaikan. Dua organisasi nonpemerintah, Lembaga Bantuan Hukum Asosiasi Perempuan Indonesia untuk Keadilan (LBH APIK) Jakarta dan Mitra Perempuan, melaporkan catatan situasi perempuan tahun 2005 yang memperlihatkan perbaikan keadaan perempuan dan pada saat sama masih memprihatinkan... .

Kedua organisasi tersebut mencatat naiknya jumlah perempuan yang melaporkan kekerasan yang mereka alami. Mitra Pèrempuan mencatat sepanjang tahun.lalu jumlah perempuan yang mengadukan kasusnya ke lembaga ini di Jakarta, Tangerang, dan Bogor sebanyak 455 kasus, naik sebanyak 38,3 persen dibandingkan dengan tahun 2004. Demikian pula jumlah pengaduan kasus kekerasan terhadap perempuan yang dilaporkan kepada LBH APIK meningkat dari 817 kasus pada tahun 2004 menjadi 1.046 kasus tahun 20005.

Kebanyakan kasus yang masuk adalah tentang kekerasan dalam rumah tangga. Naiknya jumlah perempuan yang mengadukan kasusnya ini memperlihatkan lahirnya Undang-Undang Nomor 23 Tahun 2004 Penghapusan Kekerasan Dalam 'Rumah Tangga (UU PKDRT) telah menyebabkan masyarakat tidak lagi menganggap kekerasan dalam rumah tangga sebagai masalah privat. Undang-undang ini juga memberi akses kepada korban untuk mencari penyelesaian melalui jalur hukum. Meskipun jumlah korban yang melapor meningkat, tidak semua korban bersedia menyelesaikan kasusnya. Kasus LBH APIK memperlihatkan, dari seluruh kasus yang masuk sebanyak 314 kasus adalah kekerasan dalam rumah tangga. Namun, hanya 19 kasus di antaranya yang dilaporkanke kepolisian dan darij jumlah itu hanya delapan kasus yang diproses dengan menggunakan pasal-pasal dalam UU PKDRT. Dari „kedelapan kasus tersebut, enam adalah kasus kekerasan fisik, satu kasus kekerasan ekonomi, dan satu kekerasan psikis. Hubungan pelaku dengan korban adalah suami pada istri (enam kasus), orangtua pada anak (satu kasus), dan majikan dengan pekerja rumah tangga (satu kasus).

Pada kasus-kasus lainnya pihak kepolisian tetap menggunakan Kitab UU Hukum Pidana yang kurang memberi keadilan kepada pelaku. Ketidakpuassan terhadap KUHP itulah yang akhirnya 
melahirkan UU PKDRT. Di sisi lain LBH APIK mencatat ada kemajuan dalam sikap aparat. Misalnya, mereka tidak lagi menolak membuat Surat Tanda Penerimaan Laporan Pengaduan dengan alasan masalah yang dilaporkan adalah masalah rumah tangga. Aparat juga tidak lagi berpihak pada pelaku kekerasan, bahkan mencari kesalahan pelaku. Aparat juga tidak lagi berupaya mendamaikan pelaku dengan korban walaupun korban sebenarnya tidak mau berdamai. Jika terjadi perdamaian dan perkara dicabut berdasarkan kasus yang ditangani LBH APIK semata-mata karena keinginan korban/pelapor.

\section{Khawatirkan proses hukum}

Sedikitnya kasus yang masuk ke LBH APIK dan kemudian diselesaikan melalui jalur hukum memiliki berbagai latar belakang. Kekhawatiran bahwa bila pelaku (suami) dihukum akan berdampak pada anak-anak yang akan diejek lingkungannya dengan "ayah kamu penjahat", khawatir atas biaya untuk kehidupan sehari-hari dan pendidikan anak-anak, dan khawatir atas balas dendam yang akan dilakukan pelaku pada korban (istri dan atau anak-anak) selepas pelaku dari hukumani. Namun, menurut pengalaman LBH APIK kekhawatiran terbesar korban melakukan penyelesaian hukum adalah sistem hukum tidak berpihak kepada korban sehingga akhirnya korban justru tidak mendapat kepastian hukum. Dalam diskusi laporan LBH APIK yang berlangsung di Jakarta awal Januari lalu, seorang penyintas yang kini menjadi paralegal LBH APIK secara pribadi menuturkan pengalaman mereka mengurus perceraian di pengadilan agama. Lilis mengatakan, di datang tujuh kali ke pengadilan agama untuk menuntut hak nafkah sebagai istri dan hak nafkah anaknya yang ditelantarkan suami. Itu pun kasusnya belum selesai karena suaminya yang menikah lagi tanpa izinnya masih banding. Seorang penyintas lain mengatakan, dia mengeluarkan uang hingga Rp 2 juta untuk melicinkan jalannya sidang gugatan perceraiannya di Pengadilan Agama Bekasi. Tanpa uang, tak mungkin sidang perceraian saya selesai cepat. Ada yang sampai 17 kali bolak-balik ke pengadilan dan enggak putus- putus gugatan cerainya, katanya.

Pengaiaman dua perempuan tersebut menggambarkan kesulitan yang dialami perempuan ketika menempuh jalur hukum. Selain itu, ada biaya yang harus dikeluarkan untuk mondar- mandir ke pengadilan. Persoalan ini sebetulnya telah dialami lama oleh kedua lembaga pendamping korban ini. Untuk mengatasi kesulitan tersebut, keduanya mencoba menggalang jejaring kerja dengan lembaga advokat. Mitra Perempuan beberapa kali membuka komunikasi dengan organisasi advokat dan LBH APIK Jakarta berhasil mengajak para advokat yang pernah mengikuti pelatihan bantuan hukum berperspektif jender oleh APIK membentuk Aliansi Advokat dan Pekerja Bantuan Hukum untuk Penanganan Kasus Kekerasan terhadap Perempuan. Peran advokat untuk memberi bantuan hukum dan pendampingan kepada korban secara pro bono alias gratis dimungkinkan karena di dalam UU PKDRT Pasal 26 Ayat (1) disebutkan bahwa korban berhak melaporkan langsung kekerasan dalam rumah tangga kepada kepolisian di tempat kejadian perkara atau di tempat korban berada dengan didampingi advokat. Pasal 29 juga menyebutkan permohonan untuk memperoleh surat perintah perlindungan juga diajukan oleh advokat bekerja sama dengan kepolisian, sukarelawan pendamping, pembimbing, dan pelayanan kesehatan. LBH APIK juga berhasil melahirkan 38. paralegal, yaitu para penyintas mitra LBH APIK 
yang berhasil menyelesaikan persoalan kekerasan yang mereka alami dan kemudian bersedia menjadi narasumber bagi korban yang memerlukan bantuan informasi maupun dukungan.

\section{Tantangan dan peluang}

Di luar persoalan kekerasan di dalam rumah tangga, situași perempuan yang menjadi konstituen LBH APIK belum memuaskan. Perempuan yang dilacurkan masih dianggap sebagai pelaku kriminal dan bukannya korban ketidakmampuan negara memberi lapangan kerja yang memadai untuk mengatasi kemiskinan. Pengkriminalan terhadap mereka dapat dilihat dari berbagai penertiban oleh aparat tramtib yang mengejar-rigejar pekerja seks seperti mengejar pelaku kriminal. Padahal, di antara mereka ada yang merupakan korban perdagangan orang dan karena ketidakmampuan mencari lapangan kerja lain yang memberi penghasilan layak. Persoalan lain menyangkut tenaga kerja perempuan yang mengalami pemutusan hubungan kerja setelah pemerintah menaikkan harga bahan bakar minyak bulan November 2005. LBH APIK mencatat lebih dari 10 pabrik garmen di Kawasan Berikat Nusantara Cakung menutup usahanya dengan cara pemiliknya kabur. Hampir 90 persen buruh di pabrik garmen adalah perempuan sehingga kebijakan pemerintah tersebut juga menyengsarakan perempuan. Apabila dilihat satu per satu, masih terjadi kasus buruh perempuan yang haknya tidak dipenuhi, yaitu upah di bawah upah minimum, dilarang bergabung dengan serikat buruh, kamar mandi tidak layak, tidak dipenuhi kesehatan dan keselamatan kerja, dan tidak diakomodasinya hak atas kesehatan reproduksi. Salah satu kasus menyangkut seorang buruh yang dipotong gajinya saat hamil dengan alasan kehamilannya mengurangi produktivitasnya. Pekerja rumah tangga adalah kelompok lain yang rentan terhadap kekerasan, baik fisik, ekonomi, psikis, maupun seksual. Banyak dari mereka tidak berani mengungkap kekerasan yang dialaminya karena mereka membutuhkan upah yang diterimanya untuk menghidupi keluarga di kampung.

Dari sisi undang-undang, sampai sekarang belum juga diselesaikan penyusunan UU Antiperdagangan orang, amandemen UU Kesehatan yang isinya antara lain memberikan kepada perempuan hak atas kesehatan reproduksinya dan melindungi perempuan dari aborsi tidak aman yang selama ini terjadi meskipun secara hukum dilarang, UU Perlindungan Saksi, Amandemen UU Kewarganegaraan yang isinya mendiskriminasi perempuan, dan.UU Revisi KUHP. Sebagian isi dari RUU yang akan diajukan ke DPR itu isinya masih mengkriminalkan perempuan, seperti UU Revisi KUHP dan RUU Antipornografi. dan Pornoaksi yang tidak memiliki sensitivitas bahwa perempuan adalah korban ketika dia menjadi pekerja seks atau terlibat dari pornografi. Meskipun demikian, terdapat peluang untuk memperjuangkan perbaikan posisi perempuan. Dalam penyusunan peraturan pemerintah UU -PKDRT, Departemen Hukum dan HAM: terbuka dalam menerima masukan kelompok perempuan. Ada keinginan dari Kejaksaan Agung untuk merespons kasus-kasus kekerasan terhadap perempuan (KTP). Selama ini dari pemantuan dan pendàpingan LBH APIK terhadap korban, lembaga kejaksaan adalah yang paling tidak sensitif dalam merespons kasu's kekerasan terhadap perempuan. Di tingkat masyarakat, KDRT sebagai perbuatan kriminal semakin tersosialisasi. Masyarakat merespons bukan hanya dengan membuat laporan, tetapi juga membuat lembaga pendamping 
dan rumah aman berbasis karang taruna dan women crisis center berbasis pesantren, seperti Pusat Penanganan KTP Puan Amal Hayati di Pesantren Cipasung, Tasikmalaya, dan Pesantren As-Sakienah di Indramayu. Saat situasi Timur Tengah memanas, Ahad (13/8) pihak keamanan Inggris bekejja sama dengan FBI menangkap sekitar 20 pemuda Muslim warga Inggris keturunan Pakistan. Mereka disinyalir akan melakukan serangkaian peledakan pesawat-pesawat Amerika yang berangkat dari London menuju New York. Konon itu akan dilakukan tepat lima tahun setelah peristiwa 11 September 2001

Menyusul penangkapan itu, Presiden George W Bush muncul di depan publik. Dengan bangga dia mengatakan bahwa pemerintahannya telah berhasil menggagalkan apa yang disebutnya sebagai rencana pembunuhan massal oleh kelompok Muslim ekstrim. Tentu saja ini memberi keuntungan politik buat Bush dan partai Republik. Akhir-akhir ini Gedung Putih menuai kritik dan sinisme dari publik Amerika akibat kebijakan perang Irak yang tidak kunjung jelas ujungnya dan sikap diam Washington terhadap serangan agresi brutal lsrael.

\section{Isu Terorisme dan Cara Mencegahnya}

Apa sebenarnya yang akan dilakukan oleh 20 Muslim yang ditangkap tersebut? Seperti yang dituduhkan oleh intelijen Inggris, mereka akan meledakkan sepuluh pesawat sipil Amerika menggunakan cairan nitrogliserin. Sebagai pemicunya adalah benda elektronik seperti ponsel dan kamera digital. Serta merta seluruh penumpang yang akan menuju ke Amerika dilarang membawa barang elektronik dan cairan apapun ke dalam kabin pesawat. Ibu yang membawa susu anaknya harus terlebih dahulu mencicipi sebelum diperbolehkan membawa susu tersebut ke dalam pesawat. Dapat dibayangkan betapa repotnya sistem pengecekan yang harus dilalui setiap penumpang. Apakah dengan ditangkapnya 20 Muslium tersebut akan mengurangi ancaman terorisme terhadap Amerika? Apakah pelarangan cairan dan benda elektronik dalam kabin pesawat akan menghindari pesawat-pesawat Amerika dari kemungkinan peledakan? Tentu saja tidak. Ancaman terorisme tidak selesai hanya dengan menangkap segelintir pemuda berjubah dan berjanggut. Terorisme adalah sebuah fenomena antitesa dari superiotas teknologi yang digunakan oleh Amerika untuk membangun (meminjam istilah Ahmadinejad) sebuah imperium. Sejarah justru menunjukkan bahwa terorisme adalah produk politik dominasi Amerika. Terorisme tidak ada dalam kosà kata Islam, kelompok yang sering diidentikkan dengan kejahatan kemanusiaan itu. Kata tersebut justru diciptakan dan didefinisikan oleh Amerika dan sekutunya dalam melawan kekuatan anti-Amerika.

\section{Superioritas Teknologi}

Sangat jelas bahwa dominasi Amerika dimungkinkan oleh teknologi. Jika diamati sekilas, teknologi modern memang penuh pesona. Dia menawarkan kenyamanan dan kemudahan. Tetapi pada saat yang bersamaan teknologi juga menawarkan cara-cara memenuhi hasrat dan kekuasaan. Bahkan lebih menakutkan lagi, dia dapat dengan mudah menjadi alat kekerasan.

Filosof teknologi Don Ihde menulis dalam bukunya Technology of the Lifeworld bahwa teknologi bukanlah sebuah entitas yang memiliki makna permanen (fixed meaning). Gunting bisa menjadi alat memotong kain tapijuga dapat menjadi alat membunuh 
yang menakutkan. Bagaimana fungsi-fungsi kekerasan ini muncul sangat tergantung pada konteks relasi antara manusia dan teknologi tersebut. Tetapi bukan berarti teknologi adalah benda netral seperti pendapat yang mengatakan bahwa senjata bukanlah alat membunuh sebelum pelatuknya ditarik oleh seseorang.

Kekerasan adalah hasil dari imajinasi manusia dalam melihat potensi kekerasan yang melekat dalam teknologi. Dalam dunia yang penuh dengan politik dominasi yang dilakukan oleh Amerika, teknologi selalu memiliki potensi yang dapat dengan mudah ditransformasi menjadi media kekerasan dalam mencapai tujuan-tujuan politik.

Selama kurun dua abad terakhir, Amerika telah membangun sebuah kebudayaan teknologi yang tidak pernah ada sebelumnya. Kereta api, listrik, telepon, mobil, pesawat ulang-alik, hingga internet, dan telepon seluler. Itu adalah contoh produkproduk. teknologi yang lahir dari sistem kapitalisme Amerika yang luar biasa. Kesemiuanya menawarkan berbagai mimpimimpi modernitas yang menjadikan manusia sebagai penguasa alam.

Tetapi pada saat yang bersamaan seluruh sistem teknologi yang dibangun juga menawarkan kemungkinan yang paling buruk yang pernah terjadi bagi peradaban manusia, yakni pembantaian dan penghancuran umat manusia. Ini adalah konsekuensi yang tidak terelakkan dari materialitas teknologi yang tidak pernah netral dalam konteks sosial di manapun.

Selama puluhan tahun, Amerika telah menghabiskan puluhan triliunan dolar AS untuk mengembangkàn teknólogi pembunuh massal yang tidak pernah terbayangkan sebelumnya. Lébih dari 60 persen belanja riset dihabiskan untuk sektor militer. Berbagai institusi riset dan universitas terkenal seperti MIT, Carnegie Mellon, dan Stanford ikut terlibat di dalamnya. Kesemuanya itu dilakukan bukan sematamata untuk pertahanan dalam negeri,tetapi untuk tujuan politik dominasi yang dilakukan Amerika terhadap bangsa-bangsa lain. Tumbangnya rezim komunisme tidak mengurangi upaya Amerika menciptakan jenis senjata baru. Justru penciptaan teknologipemusnah semakin intensif untuk mendukung legitimasi kekuatan politik Amerika di segala penjuru dunia:

\section{Senjata Makan Tuan}

Amerika lupa bahwa teknologi tidak pernah statis. Ketika Amerika sibuk membangún senjata-senjata pemusnáh, tanpa disadari mereka yang terdominasi juga sibuk menciptakan âlat-alat perlawanan yàng tidak terbayangkan oleh Amerika. 'Di sinilah teknologi sipil yang dikembangkan Amerika justru dimaknai oleh kelompök antiAmerika sebagai media-perlawanan. Pesawat Boeing yang diciptakan sebagai alat transportasi dimaknai sebagai alat pembunuh massal yang sangat menakutkan. Dengan sedikit. keahlian teknik, kamera digitalpun berubah menjadi pemicu bom atau ponsel sebagai detonator. Imajinasi kekerasan ini seperti tidak ada batasnya. Ironisnya, kelompok 'teroris' tidak menciptakan teknologi mereka sendiri, tetapi menggunakan berbagai tekṇologi ciptaan Amerika untuk menghantam kembali sang imperium. Peristiwa 11 September adalah contoh mengerikan bagaimana seluruh sistem teknologi yang dibangun oleh Amerika dapat menjadi mesin pembunuh bagi wargänya sendiri.

Bagaimanapun kekerasan adalah șesuatu yang harus dikutuk. Tidak ada satupun bangsa di dunia yang berhak melakukan tindakan kekerasan atas nama 
apapun. Tidak bagi Amerika, juga tidak bagi kelompok-kelompok anti-Amerika. Amerika seharunya menyadari bahwa keamanan dan perdamaian dunia tidak dapat tercipta melalui tindakan kekerasan. Secanggih apapun teknologi pertahanan yang diciptakan oleh Amerika tidak akan menghilangkan terorisme. Terorisme lahir sebagai akibat dari konflik politik, bukan teknologi. Satu-satunya cara agar warga Amerika senantiasa aman dari ancaman terorisme adalah dengan mengubah orientasi politik dominasi Amerika. Masyarakat dunia tidak membenci Amerika. Amerikalah yang membuat masyarakat dunia membenci dirinya. Sudah saatnya Amerika sadar bahwa dunia ini tidak sederhana. Hanya dengan mengapresiasi perbedaan yang ada Amerika dapat hidup damai bersama bangsa-bangsa yang lain.

\section{Penutup}

Kekerasan dan Terorisme adalah antitesa dari superioritas teknologi yang digunakan Amerika untuk membangun sebuah imperium teknologi adalah salah satu alat yang digunakan Amerika untuk menjalankan politik dominasi Dominasi ini kemudian memicu dijadikannya teknologi sebagai alat kekerasan. Pada gilirannya, teknologi yang dibangun Amerika untuk mendominasi dunia politiknya agar aman dari ancaman Amerika harus segera mengubah orientasi dominasi politiknya.

\section{Daftar Pustaka}

Baron, Marcia W., 1997.Three Methods of Ethics. Oxford: Blackwell.

Baumgarth, William P. (ed.). 1988. Saint Thomas Aquinas On La. Morality. and Politic. Cambridge: Hacket.
Bertrand, Jacques. 2004. Nationalism and Ethnic Conflict in Indonesia. Cambridge: Cambridge University Press.

Clark, Simon. (Pnyt.). 1991. The State Debate. London: Macmillan

Cribb, Robert: 1999. Nation: Making Indonesia. Dalam Donald K. Emerson (penyt). Indonesia Beyond Soeharto: polity, economy, society, transition. New York: An East Gate Book. Hal. 3-38.

Franz Magnis-Suseno. 2001. Pemikiran Karl Marx. Dari Sosialisme Utopis ke Perselisihan Revisionism. Jakarta: PT Gramedia Pustaka Utama.

Irwanto, 1998 Focus Group Discussion (FGD) :, 1998. Sebuah Pengantar Praktis. Pusat Kajian Pembangunan Masyarakat. Jakarta: Universitas Katolik Indonesia Atma Jaya:

Jessop, B., The Rise of Governance and the Risk of Failure : The Case of Economic Development. International Social Science Journal, vol. 155.

Lore, Robert .K. and Schulth, L.A. 2001. Control of Human Aggression, A Comparative Perspective. American Psychologist, 48, 1625.

Lawang, R.M.Z, 1989a. Stratifikasi Sosial di Cancar. Manggarai Flores Barat. Disertasi. tidak diterbitkan

Lembaga Bantuan Hukum untuk Perempuan dan Keadilan (LBH APIK) Jakarta, (2002), Angka Kekerasan di Jakarta tahun 1998-2002, Jakarta: LBHAPIK 
Mencermati Perilaku Kekerasan dan Paradigma Sosial; Dian Wahyuni P

Mathias, J., Mertin, P. and Murray, B. 1995. Satha-Anand, Chaiwat dan Qader 'The psychological functioning of children from backgrounds of domestic violence'. Australian Psychologist. Muhaideen, 1993. "Bulan Sabit AntiKekerasan: Refleksi atas Perjuangan vol.30, no. 1 (March).

Kaum Muslim Muangthai" dalam Saiful Muzani, (Ed.), Pembangunan dan Kebangkitan Islam di Asia Tenggara. Jakarta: LP3ES. 